\title{
Observing regional-scale pack-ice decay processes with helicopter-borne sensors and moored upward-looking sonars
}

\author{
Simon J. PRINSENBERG, Ingrid K. PETERSON \\ Bedford Institute of Oceanography, Fisheries and Oceans Canada, 1 Challenger Drive, PO Box 1006, Dartmouth, \\ Nova Scotia B2Y 4AZ, Canada \\ E-mail: Simon.Prinsenberg@dfo-mpo.gc.ca
}

\begin{abstract}
The variability of Arctic pack-ice parameters (e.g. extent and ice type) has been monitored by satellite-borne sensors since the early 1960s, and information on ice thickness is now becoming available from satellite altimeters. However, the spatial resolution of satellite-derived ice properties is too coarse to validate fine-scale ice variability generated by regional-scale interaction processes that affect the coarse-scale pack-ice albedo, strength and decay. To understand these regional processes, researchers rely on other data-monitoring platforms such as moored upward-looking sonars and helicopter-borne sensors. Backed by observations, two such regional-scale pack-ice decay processes are discussed: the break-up of large pack-ice floes by long-period waves generated by distant storms, and the spring decay of first-year-ice ridges in a diverging pack-ice environment. These two processes, although occurring on regional spatial scales, are important contributors to the evolution of the total pack ice and need to be included in global climate models, especially as the conditions for their occurrence will alter due to climate change.
\end{abstract}

\section{INTRODUCTION}

It is now generally accepted that due to climate change, the Arctic polar ice cap is melting (ACIA, 2005; Solomon and others, 2007). Indeed, in 2007 and 2008 the September Arctic ice extent was at record low levels for the past 30 year period during which satellite imagery has been available to document ice extent accurately (US National Snow and Ice Data Centre, http://nsidc.org). However, climate models have difficulty in simulating the present Arctic ice extent, and thus may not predict future conditions accurately. Global models use very coarse grids, and cannot incorporate small-scale processes that finescale regional models have shown are important for simulating the evolution of the Arctic pack ice (W. Maslowski and others, https://www1.cmos.ca/abstracts/ abstract_print_view.asp?absld=2010). Two such regionalscale pack-ice decay processes, along with observations, are discussed in this paper: the break-up of large pack-ice floes by long-period waves generated by distant storms, and the spring decay of first-year ice ridges in a diverging packice environment.

Observations to validate these processes were obtained with helicopter-borne sensors and moored upward-looking sonars (ULSs). A helicopter-borne electromagnetic (HEM) laser system sampling at $10 \mathrm{~Hz}$ provided ice-plus-snow thickness and ice surface roughness profiles, with a spatial sampling interval of $\sim 4 \mathrm{~m}$ at a normal helicopter survey speed of $80-100 \mathrm{mph}\left(130-160 \mathrm{~km} \mathrm{~h}^{-1}\right)$. The footprint size of the HEM sensor depends on the height of the sensor above the sea water, and is $\sim 18-25 \mathrm{~m}$ when flying at $5 \mathrm{~m}$ over $2-5 \mathrm{~m}$ thick ice. A second Video-Laser system collects images from which mosaics are made from overlapping frames. Peterson and others (2003) provide descriptions of the helicopter-borne sensors. Hourly ice-drift and ice-draft data were collected with acoustic Doppler current profilers (ADCPs) and ULSs. In addition to ice drift, the ADCP collects ocean-current velocity data at specified depths.

\section{BREAK-UP OF BEAUFORT SEA PACK ICE BY LONG- PERIOD WAVES}

During summer 2009, from 28 August to 12 September, ice observations were collected using sensors on board a helicopter stationed on CCGS Amundsen while it traversed the Canadian Beaufort Sea pack ice (red box, Fig. 1). The pack ice encountered consisted of thin 'rotten' first-year ice, $50-75 \mathrm{~cm}$ thick, and thicker (2-3 m) old ice that contained melt ponds (Barber and others, 2009). The surface salinity of both the rotten and old ice was $\sim 3$ psu in the middle, decreasing towards the surface and bottom, and the ice, air and water temperatures were $\sim 0^{\circ} \mathrm{C}$. The low salinity and warm temperature of the ice made the pack ice very weak (Timco and Johnston, 2002), so it did not present an obstacle to the icebreaker. Upon arriving on 6 September at the multi-year ice (MYI) station (red star, Fig. 1) within the thicker and more consolidated pack ice, long-period waves with a $13.5 \mathrm{~s}$ period, but reducing over time, appeared to come from the northwest. They occurred for several days, breaking the large 2-3 km pack-ice floes into smaller floes of $<100 \mathrm{~m}$ (Prinsenberg and others, 2010). While the Amundsen traversed the pack ice eastwards towards the MYI station on 6 September, a $\sim 40 \mathrm{~km}$ HEM ice-thickness profile was collected (Fig. 2). It captured the change from the thinner, 'rotten' ice to the thicker pack ice, at the latitude where large MYI floes, several kilometres in diameter, with melt ponds existed. The change in ice regime occurred at $133.37^{\circ} \mathrm{W}$, where the Amundsen tried to establish the MYI station for on-ice sampling (Barber and others, 2009).

The mean ice thickness west of the MYI station, located approximately at sample No. 3500 (Fig. 2a), was $0.92 \mathrm{~m}$. The ice was highly concentrated, with only $3.0 \%$ of openwater sections. Some old-ice floes within this thinner pack ice had ice thicknesses as high as $4 \mathrm{~m}$ (spatially averaged over $25 \mathrm{~m}$ ). East of the MYI station, the thicker pack ice had a mean thickness of $2.26 \mathrm{~m}$, but leads were present, as $2.0 \%$ of open-water sections along the flight path were observed. 


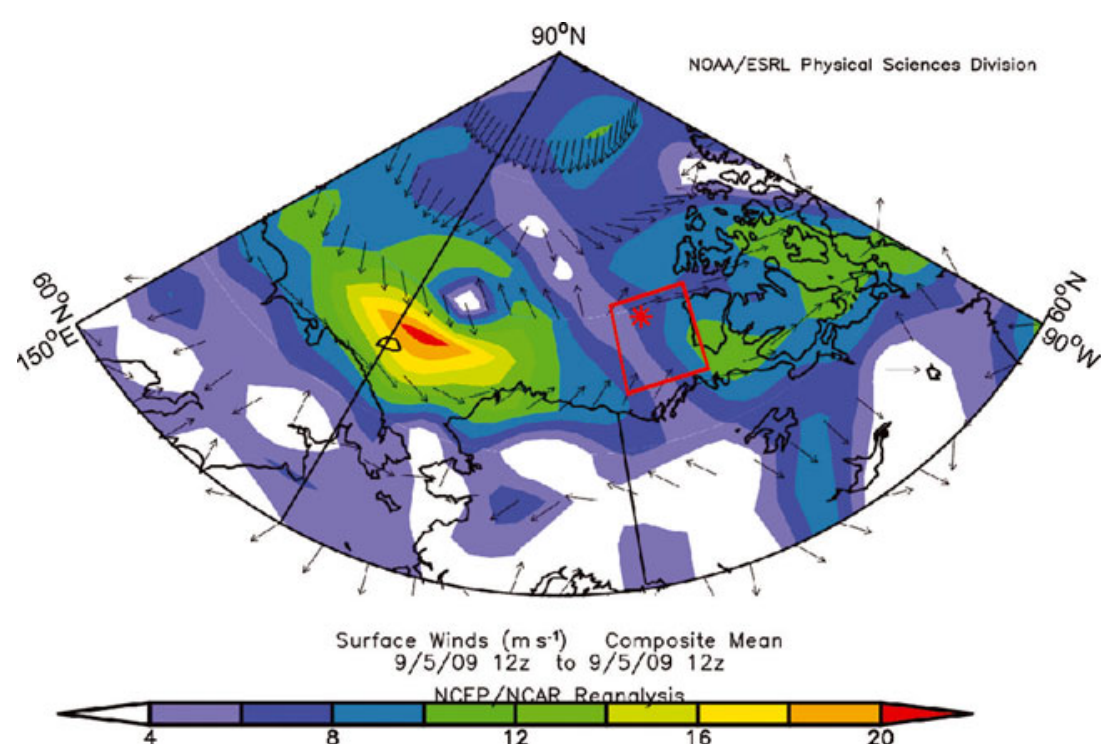

Fig. 1. Map of the Arctic Ocean and the region (red box) where ice-property data were collected with helicopter-borne sensors during summer 2009. Also shown are wind velocities generated by an atmospheric low north of Bering Strait at $82^{\circ} \mathrm{N}$, moving north into the Arctic Ocean. Image provided by the US National Oceanic and Atmospheric Administration (NOAA)/NASA Earth and Space Research Laboratory (ESRL) Physical Sciences Division, Boulder, CO, from their website at http://www.esrl.noaa.gov/psd/.

Floe thicknesses were as high as $8 \mathrm{~m}$ in this pack-ice section. The thick multi-year ice around the MYI station was heavily decayed as the Amundsen was able to break through thick 6-8 $\mathrm{m}$ floes. The open-water fraction along the total line was $2.6 \%$ (Fig. 2C). The two different ice regimes east and west of the MYI station had very similar microwave scattering and emission characteristics, making it difficult to differentiate them using synthetic aperture radar (SAR) data (Barber and others, 2009).

Upon returning to the Amundsen at noon on 6 September, it was noticed that the icebreaker was heaving very slowly.
Long-period waves from the northwest with a period of $13.5 \mathrm{~s}$ had appeared in wave packets. Over the next 2 days, the waves grew in amplitude, while their period decreased over time. They broke up the large $2-3 \mathrm{~km}$ pack-ice floes into smaller floes of $<100 \mathrm{~m}$. A fix-mounted video camera on the helicopter collected video frames and documented the start of the break-up of the floes. Mosaics plotted with north up were collected at $125-130 \mathrm{~m}$ altitude, providing a video frame width of 135-140 m. Mosaic 57990, collected at 1044 MDT (Mountain Daylight Time) (Fig. 3a), shows how the waves had already broken up the thinner 'rotten' first-year
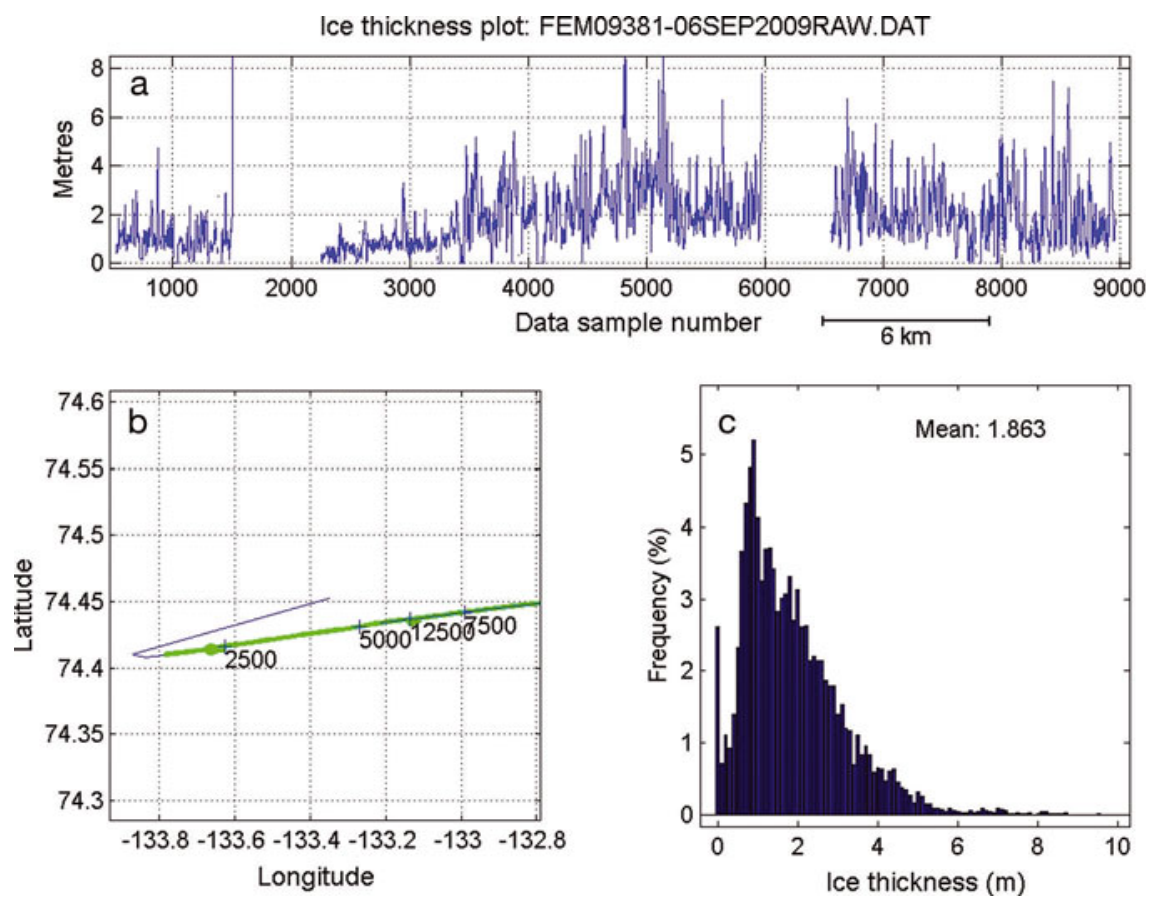

Fig. 2. Ice-thickness profile collected from west to east on 6 September (1000-1100 Mountain Daylight Time), passing from mostly thin first-year ice to old ice at data sample No. 3500, where CCGS Amundsen was stationed at noon. (a) Ice-thickness plot. (b) Flight-path plot. (c) Ice-thickness histogram. 

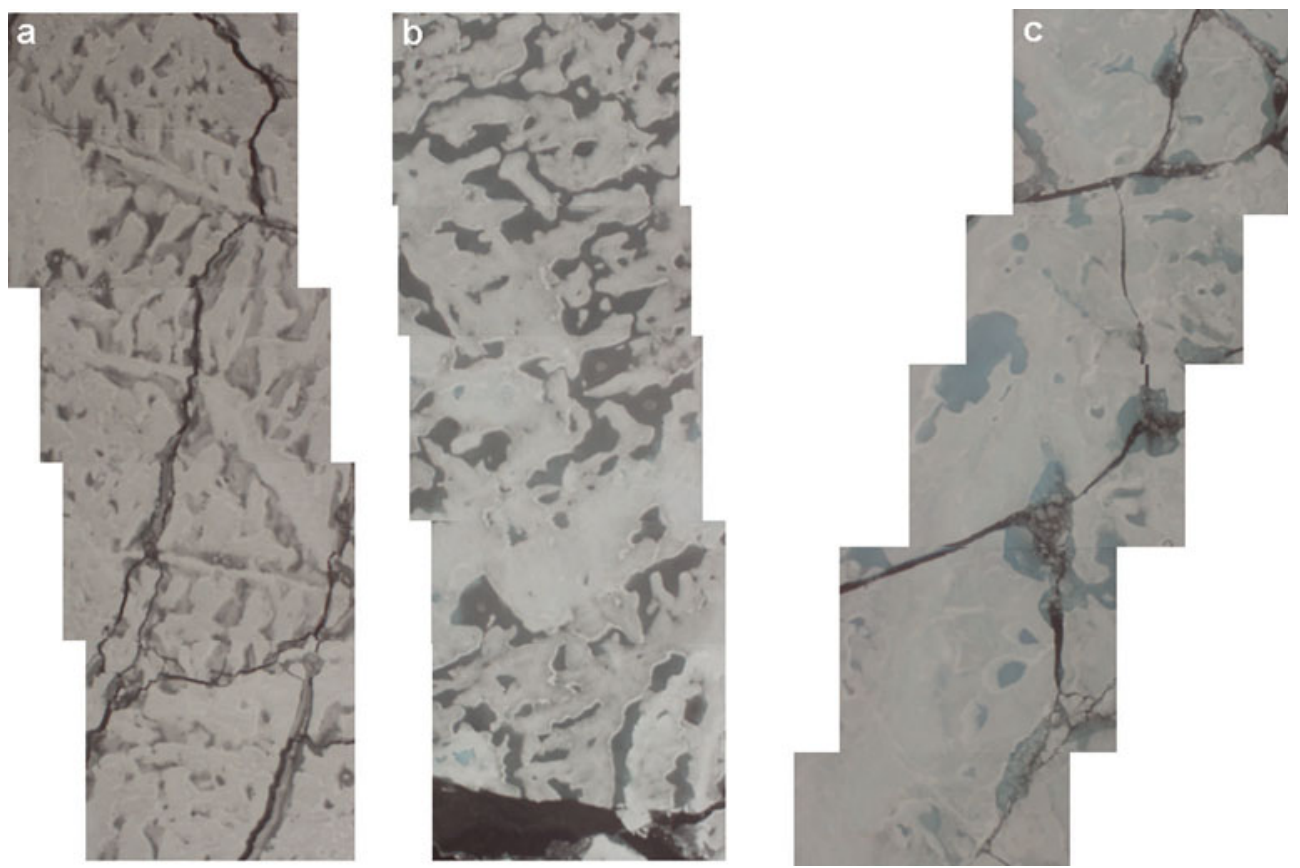

Fig. 3. (a) Mosaic 57990 collected flying north to south at $1044 \mathrm{MDT}$ at $74.76^{\circ} \mathrm{N}, 133.47^{\circ} \mathrm{W}$, and showing the 'rotten' first-year ice. (b) Mosaic 59360 collected flying north to south at $1102 \mathrm{MDT}$ at $74.47^{\circ} \mathrm{N}, 133.47^{\circ} \mathrm{W}$, and showing the unbroken thicker old ice with 'turquoise' melt ponds. (c) Mosaic 61270 collected flying south to north at $1332 \mathrm{MDT}$ at $74.49^{\circ} \mathrm{N}, 133.37^{\circ} \mathrm{W}$, and showing the thicker old ice broken up due to long-period waves.

ice north of the icebreaker, while the multi-year ice around the icebreaker was still not affected by the waves (mosaic 59360 at 1102 MDT; Fig. 3b). The rotten ice had bottomless melt ponds with a thin $5-10 \mathrm{~cm}$ new-ice cover. The width of the mosaics is 135 and $140 \mathrm{~m}$, indicating that the halfwavelength of the waves breaking up the thinner ice was $\sim 100 \mathrm{~m}$, in agreement with the half-wavelength magnitude of a deep-water wave $(140 \mathrm{~m})$ with a $13.5 \mathrm{~s}$ period (Wadhams and Doble, 2009). Two hours later, even the thicker multiyear ice started to break up into smaller floes (mosaic 61270 at 1332 MDT; Fig. 3c).

During 3-5 September, an Arctic storm had moved north from the Bering Strait over open water in the Chukchi Sea (Fig. 1). Winds (from the US National Centers for Environmental Prediction/US National Center for Atmospheric Research (NCEP/NCAR) Reanalysis dataset (Kalnay and others, 1996)) peaked at noon on 5 September (Fig. 1). While the storm was over open water, it apparently generated the long-period waves that arrived on 6 September at the MYI station, $\sim 250 \mathrm{~km}$ inside the pack ice. Since the wave-group speed depends on the wave period, with the longer-period waves travelling the fastest, the waves with the longest period arrived first, followed throughout the next 2 days by waves with decreasing wave periods (and smaller wavelengths).

The presence of long-period swells was recorded by the ship's high-frequency sonar data, which are used to correct the continuously recording multi-beam seismic depth data for ship's motion. A $5 \mathrm{~min}$ sample data plot from noon on 6 September is shown in Figure 4a. It clearly shows the longperiod swell wave packets that made the icebreaker heave, with individual waves having periods of $13.5 \mathrm{~s}$ and amplitudes as high as $0.4 \mathrm{~m}$ (group velocity $39.6 \mathrm{~km} \mathrm{~h}^{-1}$ ). A second sample on the following day is shown in Figure $4 \mathrm{~b}$. The icebreaker had moved $150 \mathrm{~km}$ to the northwest, closer to the pack-ice edge. The wave period had decreased to $8 \mathrm{~s}$ and the maximum amplitude had increased to $0.8 \mathrm{~m}$ (group velocity $22.4 \mathrm{~km} \mathrm{~h}^{-1}$ ). Assuming that both wave packets were generated the same place and time, and that the ship moved $150 \mathrm{~km}$ closer to the storm centre between 6 and 7 September, the centre of the storm was $890 \mathrm{~km}$ (1 day's travel) northwest of the MYI station, agreeing with the position of the maximum wind speed (Fig. 1).

By 9 September, the total pack ice was broken up into floes $<100 \mathrm{~m}$ in diameter, with most floes $\sim 50 \mathrm{~m}$ as shown in the photograph (Fig. 5) taken at $150 \mathrm{~m}$ altitude. That day, long ice thickness and video lines were made in an eastwest direction from the Amundsen stationed at $72.518^{\circ} \mathrm{N}$, $136.43^{\circ} \mathrm{W}$. The multi-year ice pack ice around the Amundsen (Fig. 5) had an ice concentration of $80-90 \%$; some of the turquoise-coloured melt ponds on the multi-year ice can still be seen.

Long ice-thickness profiles were collected east and west of the Amundsen on 9 September. The longest waves had penetrated $350 \mathrm{~km}$ into the pack ice to $134.5^{\circ} \mathrm{W}$, where individual floes were large (100-200 m) and did not diverge from each other. Ice along the eastern profile was generally similar to that found around the Amundsen (Fig. 3), with the concentration and floe sizes increasing towards the east, indicating less penetration of the longer-period swells into the pack ice. The pack ice west of the Amundsen was thinner and consisted mostly of the 'rotten' first-year ice that was now all broken up into smaller floes. Over the total line, the mean thickness was $0.74 \mathrm{~m}$ west and $1.06 \mathrm{~m}$ east of the icebreaker. Along the combined line, the open-water fraction was $5.5 \%$, as compared with $2.6 \%$ before the long-period waves appeared (Fig. 2). Although measured at different regions of the pack ice, the doubling of the open-water area would increase the heat flux into the ocean, and enhance both the lateral and bottom melt of the ice. The open-water area may be underestimated, as the electromagnetic sensor has a footprint of $25 \mathrm{~m}$ and thus does not see the numerous smaller leads. 
MYI $\left(74.4465^{\circ} \mathrm{N}, 133.37^{\circ} \mathrm{W}\right)$

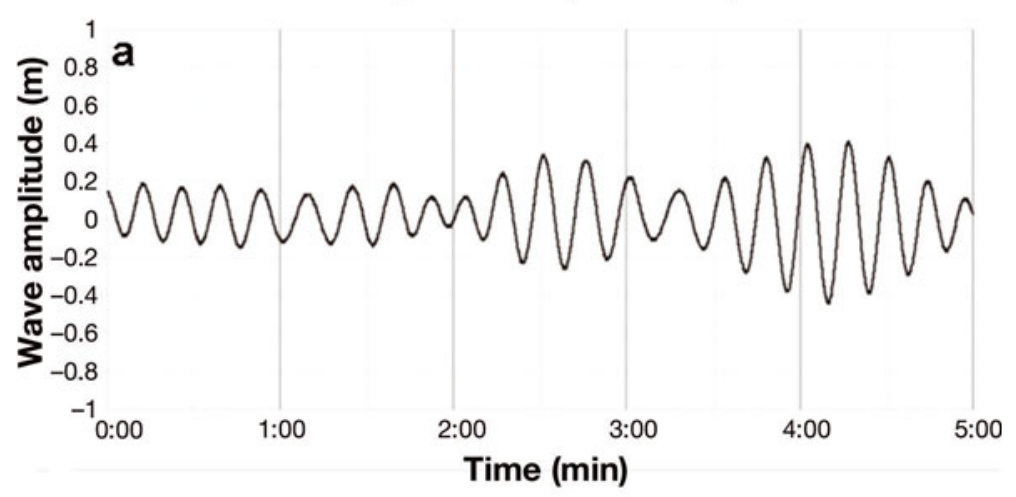

L3 $\left(75.3341^{\circ} \mathrm{N}, 137.704^{\circ} \mathrm{W}\right)$

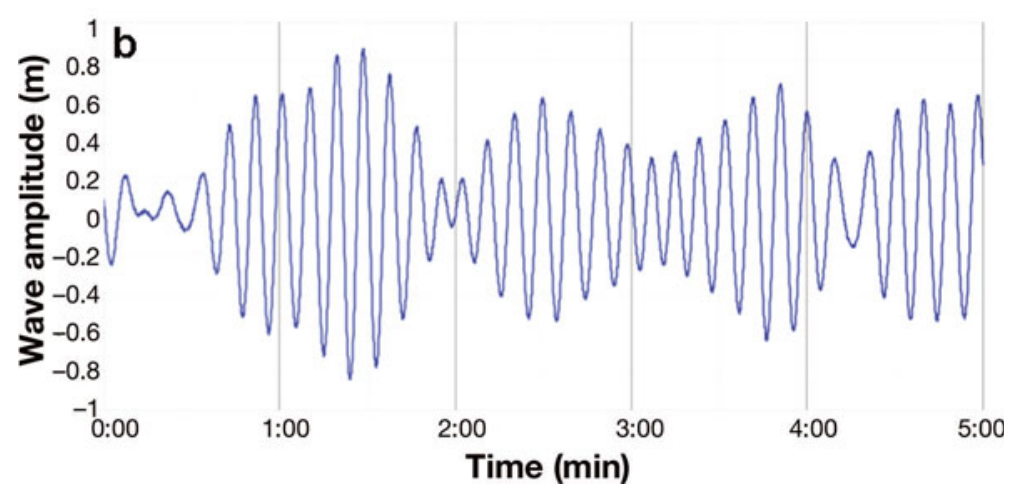

Fig. 4. High-frequency ship sonar data (courtesy I. Church, University of New Brunswick, Canada): (a) from 6 September at $1203-1205$ MDT, and (b) from 7 September at 1201-1202 MDT.

\section{THE COLLAPSE OF FIRST-YEAR ICE RIDGES IN A DIVERGING PACK-ICE ENVIRONMENT}

Since 2003, moored instrumentation along the Canadian east coast has been used to monitor ocean currents, ice draft and ice drift biannually, in support of possible oil and gas exploration in the area (I.K. Peterson and others, unpublished information). The mooring site is on Makkovik Bank, a region of high exploration interest, with depths of $\sim 100 \mathrm{~m}$ (Fig. 6). The area is covered by a seasonal marginal ice zone cover. The ice along the eastern ice edge is continually being melted as it mixes with warmer offshore waters, and is broken up by waves generated in the Labrador Sea. The predominant winter winds are from the northwest, and, along with the southward-drifting Labrador Current, the pack ice moves southward at $\sim 15 \mathrm{~cm} \mathrm{~s}^{-1}$ over the shelf, and $30-50 \mathrm{~cm} \mathrm{~s}^{-1}$ in the main core of the Labrador Current located near the shelf break. The southernmost extent of the pack ice advances south over the shelf during the winter, as the southward ice flux and local ice growth at the edge is larger than the ice melt. The pack ice reaches its maximum southern extent by mid-March, after which the southern edge retreats north as the ice-edge melt exceeds the southward-moving ice flux and local ice growth. As seen in the Envisat SAR image (Fig. 6), undulations with a wavelength of $\sim 75 \mathrm{~km}$ are found at the ice edge due to baroclinic instability, and travel southward with the Labrador Current at $\sim 0.2 \mathrm{~m} \mathrm{~s}^{-1}$ (LeBlond, 1982). The Labrador Current is also affected by a series of banks along the shelf that cause the current and the pack ice in it to meander, resulting in a complex water and ice circulation pattern.
Figure 7 shows the daily maximum and mean of hourly mean ice speeds for the winters of 2003, 2005 and 2007. The daily speed data were calculated from hourly ice speeds computed from ice velocities averaged on the hour for $5 \mathrm{~min}$. These data are required to compute the spatial icedraft series, and show that speeds up to $90 \mathrm{~cm} \mathrm{~s}^{-1}$ were observed in all three years. Even the daily mean values reach speeds up to $60 \mathrm{~cm} \mathrm{~s}^{-1}$. These extreme ice-drift rates, along with the presence of icebergs and thick pack ice, make the Labrador shelf a very inhospitable region for winter offshore

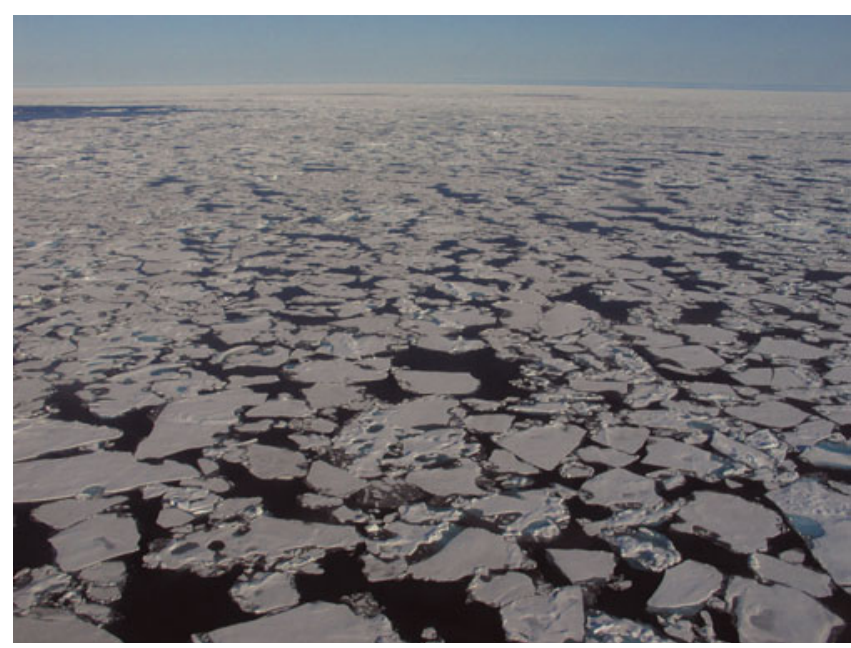

Fig. 5. Broken-up pack ice as seen from $150 \mathrm{~m}$ altitude on 9 September at $1122 \mathrm{MDT}$ at $72.51^{\circ} \mathrm{N}, 136.43^{\circ} \mathrm{W}$. 


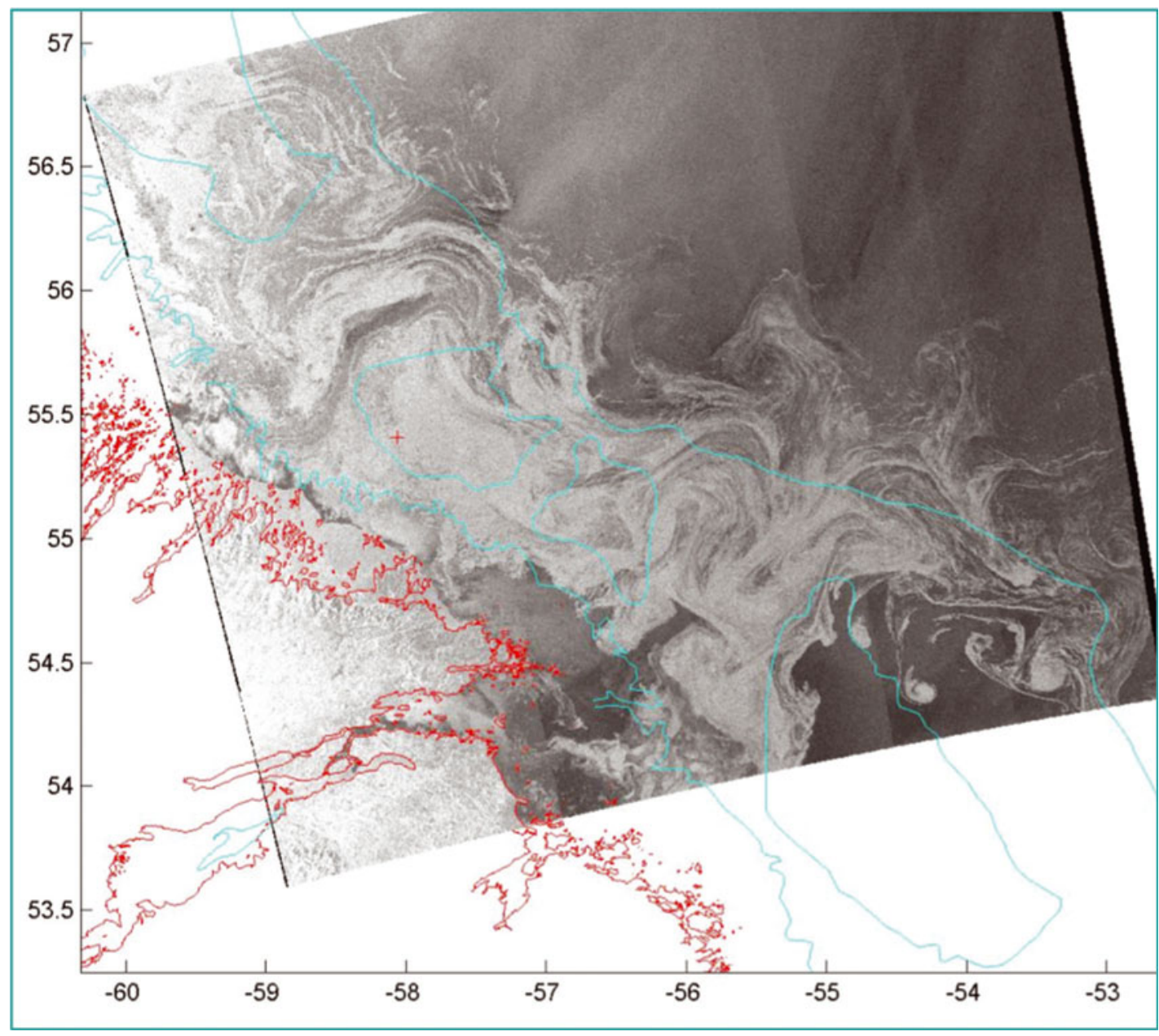

Fig. 6. Envisat SAR image of 8 April 2005 showing ice over the Labrador shelf, and covering an area of $225 \mathrm{~km} \times 225 \mathrm{~km}$. The 200 and $1000 \mathrm{~m}$ depth contours are shown, along with the mooring site (red cross). The pack ice moving south is restricted to the colder, shallower shelf region by thermodynamic processes. (C) European Space Agency 2005.
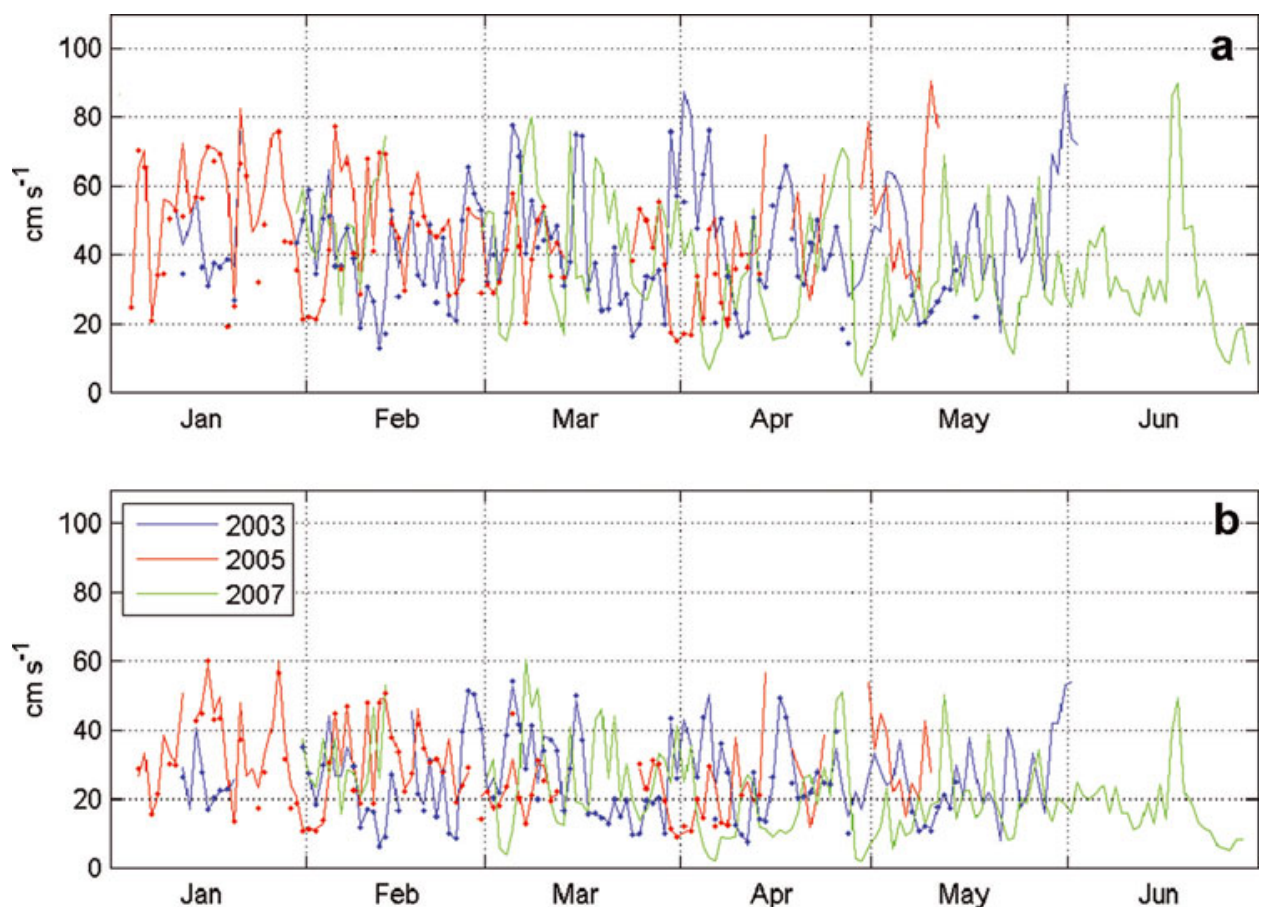

Fig. 7. Daily maximum (a) and mean (b) of hourly mean ice speeds derived from the ADCP mooring Makkovik Bank. The dots represent high-confidence data from periods when little editing was required due to high ice concentrations. The daily mean values represent at least 12 data points. 

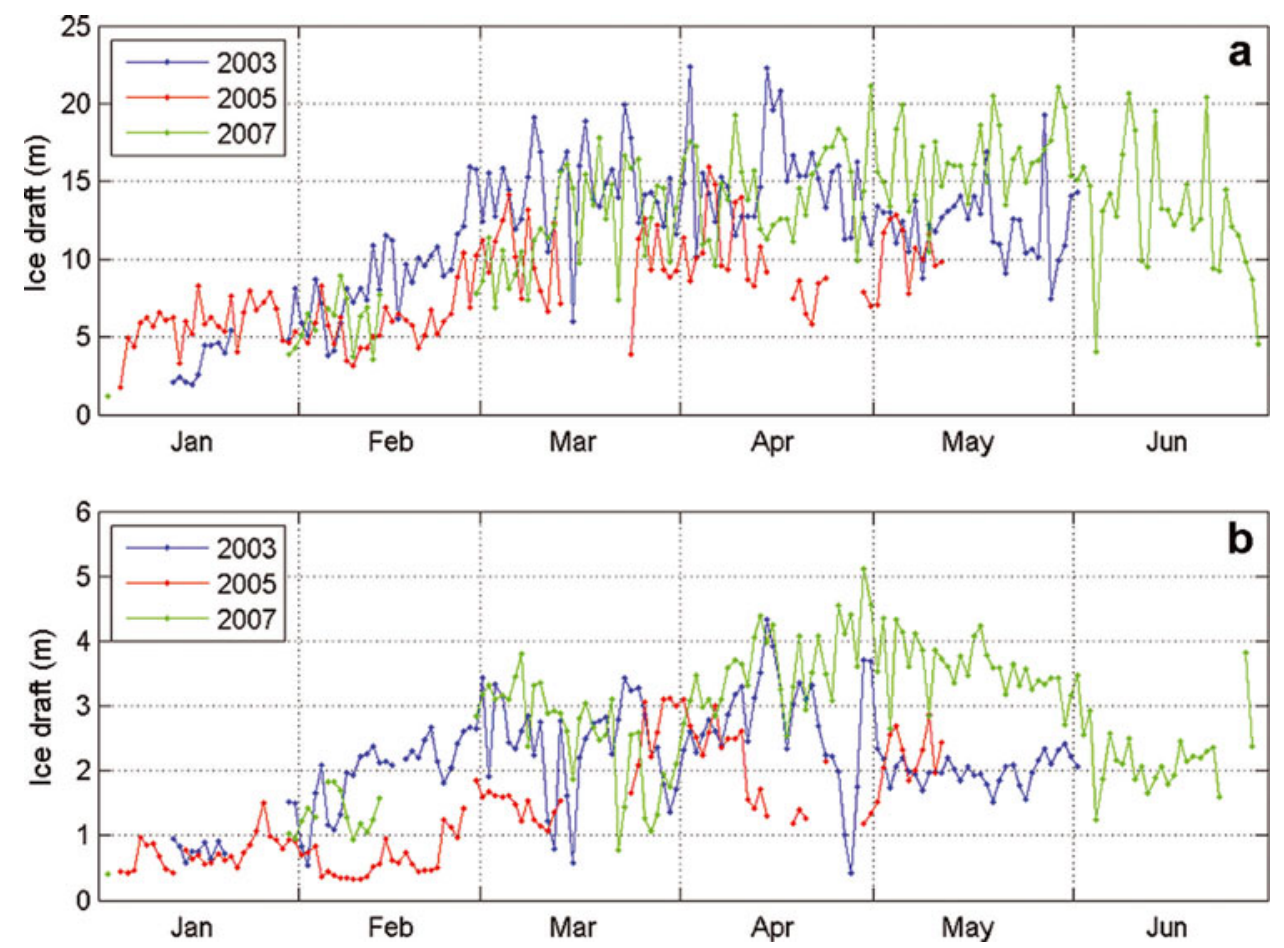

Fig. 8. Daily maximum (a) and mean (b) ice draft from Makkovik Bank for the 2003, 2005 and 2007 ice seasons.

exploration and development. The mean speeds for the spatial series in 2003, 2005 and 2007 were 26, 29 and $22 \mathrm{~cm} \mathrm{~s}^{-1}$ respectively.

The daily mean and maximum ice drafts for the winters of 2003, 2005 and 2007 are shown in Figure 8. The daily mean drafts reach a mid-winter maximum, before decreasing in spring, even with older ice and ridges formed farther north continually passing the site. Locally grown and ridged pack ice from the Labrador shelf first shows up at the mooring site, with a maximum keel draft of 5-10 m, before heavier and thicker pack ice with keels up to $20 \mathrm{~m}$ originating from northern regions appears. Some of these features may be the keels of small pieces of old ice that drifted south from Davis Strait. The mean ice thicknesses in 2003, 2005 and 2007 are $2.2,1.1$ and $2.9 \mathrm{~m}$ respectively.

What process causes these maxima in daily mean ice draft? The daily mean ice-thickness distributions reach a mid-winter maximum as ridge frequency and undeformed ice thickness attain the apparent maximum. The annual decrease in mean ice-draft thickness occurs at different times for each year: on about day 113, 100 and 140 for 2003, 2005 and 2007 respectively. In 2003 and 2005, these dates also corresponded to the times when ice concentration (Fig. 9b) decreased below 1.0. In 2007, the ice concentration remained high until day 154 . The timing of these events is related to the onset of the melt season, when spring conditions arrive at the area, and which varies each year. It can be tracked by the air temperatures or, as shown in Figure 9a, by the cumulative temperature sums.

A negative slope of the cumulative temperature sums (Fig. 9) corresponds to a freezing period, while a positive slope corresponds to a melting period. It can be seen that the melt season began earliest in 2005 and latest in 2007, in agreement with the start of the decrease in mean icedraft dates in Figure 8. In 2003, melting began on day 112 similar to the start of the decrease in the mean ice draft on day 113 . In 2005, melting began on day 92, shortly before day 100 when the decrease of the ice draft started (Fig. 8). In 2007, melting began on day 120, but the temperature did not rise significantly above $0^{\circ} \mathrm{C}$ until day 138 , compared to the start of the decrease of ice draft on day 140 in Figure 8.

Thus the change in mean ice-draft thickness distribution occurred at approximately the time of melt onset. Using digital aerial photographs in the western Weddell Sea, Steer and others (2008) also found that at the time of melt onset, the floe size distribution changed suddenly due to ridges collapsing into their component parts. They stated that the observed changes in the FDS (Floe Size Distribution) could be explained by the "relaxing" of the ice pack, with ridges breaking into their component parts and drifting apart. Surface melt processes assisted here, by effectively weakening the "glue" holding the ridges together.' It seems likely that the collapse of first-year ice ridges on the Labrador shelf follows a similar process and would be enhanced by wave action, which was not the case in the Weddell Sea study (Steer and others, 2008). The collapse of first-year ridges in the marginal ice zone off Labrador will enhance the melting of the pack ice, as more ice surface area will be exposed for lateral ice melt and more radiation heat flux is absorbed by the ocean in the diverging pack-ice conditions.

It should be noted that in Figure 8 there were still significant quantities of thick ice after the transition due to ice melt. This would be expected due to the presence of more consolidated old-ice ridges transported into the area from the north. During a recent helicopter-based ice survey off the Labrador coast (March 2009) several small old-ice floes were seen, along with numerous large icebergs. Growlers and bergy bits calving from the icebergs could also be responsible for the continued large daily maximum draft features seen in the spring. 

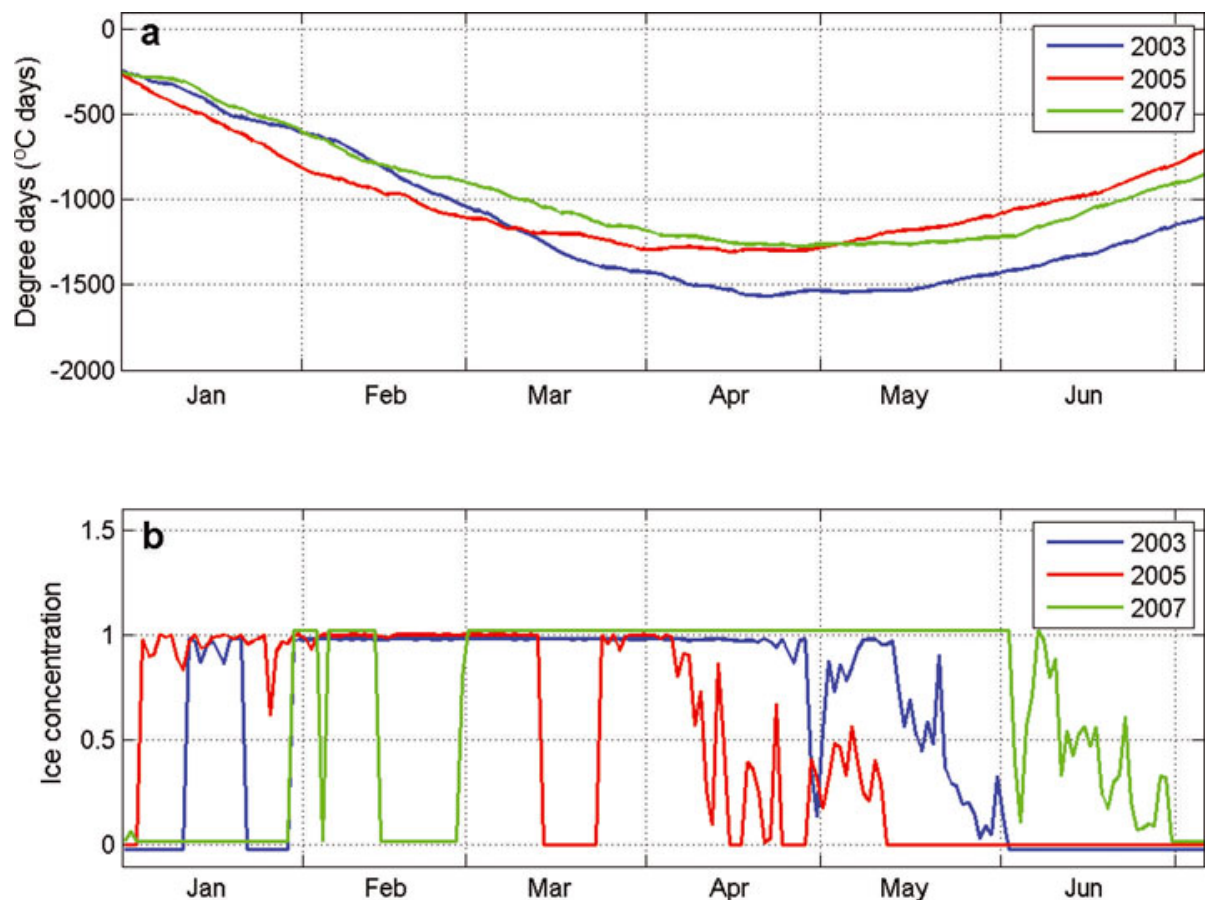

Fig. 9. Cumulative sums of daily mean air temperature (a) and ice concentrations at mooring site (b) at Cartwright, Labrador, in 2003, 2005 and 2007.

\section{CONCLUSIONS}

Two pack-ice decay processes occurring on regional spatial scales have been presented. They affect the overall pack-ice extent evolution and need to be included in global climate models, especially as the conditions for their occurrence will alter due to climate change.

Storms and open-water conditions are expected to increase in the Arctic Ocean, increasing the generation and penetration of long-period waves into pack ice, and thereby enhancing the breaking-up and melting of the pack ice. An example of such a storm event was presented for the Canadian Beaufort Sea in summer 2009, during which longperiod waves penetrated the pack ice to $350 \mathrm{~km}$ and broke up the large floes into floes of $<100 \mathrm{~m}$. The onset of the icemelt season, which is expected to occur earlier due to climate change, seems to trigger the breakdown of first-year ice ridges into their component parts in the marginal ice zone along the Labrador coast when air and water temperatures provide heat for melting. What was seen off Labrador and by Steer and others (2008) in the Weddell Sea is that these first-year ridges should not be simulated in models as thick consolidated ice, but should remain as weakly cohesive rubble fields that melt relatively quickly in spring, due to breakdown into their component parts and large lateral ice melt.

The shift to smaller floe distribution seen in the Beaufort Sea and Labrador shelf data will increase the lateral melt of the pack ice as discussed by Steele (1992), Toyota and others (2006) and Steer and others (2008), and will affect the dynamic response of the pack ice to wind forcing due to form drag (Steele and others, 1989; Squire, 2007). As theories indicate, ice thickness, ice strength and the swell wavelength will determine the floe size distribution of the pack ice (Toyota and others, 2006), but shift to smaller floes will greatly enhance the lateral ice melt of the overall pack ice.

\section{ACKNOWLEDGEMENTS}

We thank the scientific editor T. Vilma and reviewers for their help and reviews which focused and strengthened the content of the manuscript. The leader of the ArcticNet ice program, D. Barber, and personnel of CCGS Amundsen are thanked for their support of the 2009 Beaufort Sea program. The research was supported by the Canadian Space Agency's Government Related Initiatives Program, ArcticNet, Imperial Oil Canada and the Program of Energy Research and Development, Canada. Special thanks to Canadian Coast Guard pilot and engineer G. Carpentier, engineer M. Raymond and the Amundsen crew under the leadership of Captain S. Julien.

\section{REFERENCES}

Arctic Climate Impact Assessment (ACIA). 2005. Arctic climate impact assessment: scientific report. Cambridge, etc., Cambridge University Press.

Barber, D.G. and 8 others. 2009. The perennial pack ice in the southern Beaufort Sea was not as it appeared in the summer of 2009. Geophys. Res. Lett., 36(L24), L24501. (10.1029/ 2009GL041434.)

Kalnay, E. and 21 others. 1996. The NCEP/NCAR 40-year reanalysis project. Bull. Am. Meteorol. Soc., 77(3), 437-471.

LeBlond, P.H. 1982. Satellite observations of Labrador Current undulations. Atmos.-Ocean, 20(2), 129-142.

Peterson, I.K., S.J. Prinsenberg and J.S. Holladay. 2003. Sea-ice thickness measurement: recent experiments using helicopterborne electromagnetic systems. Res. Signpost: Recent Res. Devel. Geophys., 5, 1-20.

Prinsenberg, S.J., I.K. Peterson, D.G. Barber and M. Asplin. 2010. Long period swells break up the Canadian Beaufort Sea pack ice in September 2009. In Chung, J.S., R. Ayer, S. Prinsenberg, S.W. Hong and I. Langen, eds. Proceedings of the 20th International Society of Offshore and Polar Engineering Conference, 20-25 June 2010, Beijing. Vol. 1. Cupertino, CA, 
International Society of Offshore and Polar Engineers, $1155-1161$.

Solomon, S. and 7 others, eds. 2007. Climate change 2007: the physical science basis. Contribution of Working Group I to the Fourth Assessment Report of the Intergovernmental Panel on Climate Change. Cambridge, etc., Cambridge University Press. Squire, V.A. 2007. Of ocean waves and sea ice revisited. Cold Reg. Sci. Technol., 49(2), 110-133.

Steele, M. 1992. Sea ice melting and floe geometry in a simple iceocean model. J. Geophys. Res., 97(C11), 17,729-17,738.

Steele, M., J.H. Morison and N. Untersteiner. 1989. The partition of air-ice-ocean momentum exchange as a function of ice concentration, floe size and draft. J. Geophys. Res., 94(C9), $12,739-12,750$
Steer, A., A. Worby and P. Heil. 2008. Observed changes in sea-ice floe size distribution during early summer in the western Weddell Sea. Deep-Sea Res. II, 55(8-9), 933-942.

Timco, G.W. and M.E. Johnston. 2002. Sea ice strength during the melt season. In Squire, V.A. and P.J. Langhorne, eds. Ice in the Environment: Proceedings of the 16th IAHR Symposium, 2-6 December, Dunedin, New Zealand. Dunedin, International Association of Hydraulic Engineering and Research,

Toyota, T., S. Takatsuji and M. Nakayama. 2006. Characteristics of sea ice floe size distribution in the seasonal ice zone. Geophys. Res. Lett., 33(L2), L02616. (10.1029/2005GL024556.)

Wadhams, P. and M.J. Doble. 2009. Sea ice thickness measurement using episodic infragravity waves from distant storms. Cold Reg. Sci. Technol., 56(2-3), 98-101. 